\title{
Pentagalloylglucose, isolated from the leaf extract of Anacardium occidentale L., could elicit rapid and selective cytotoxicity in cancer cells
}

Bamigboye J. Taiwo ${ }^{1,2^{*}}$, Temidayo D. Popoola ${ }^{3}$, Fanie R. van Heerden ${ }^{2}$ and Amos A. Fatokun ${ }^{3 *}$ (D)

\begin{abstract}
Background: The leaf of Anacardium occidentale L. has been a component of many herbal recipes in SouthWestern Nigeria. The work reported herein, therefore, explored the phytochemical composition of this plant and the potential anti-cancer activity of an isolated chemical constituent.

Methods: Phytochemical methods (including chromatographic analysis) combined with spectroscopic and spectrometric analyses (IR, HRMS and NMR (1D and 2D)) were used to identify chemical constituents. Cytotoxic effects were determined using the MTT viability assay and bright-field imaging. Induction of oxidative stress was determined using the fluorescence-based 2',7'-dichlorofluorescein diacetate (DCFDA) assay.

Results: For the first time in the plant, Compound 1 was isolated from the leaf extract and identified as pentagalloylglucose. Compound 1 was significantly cytotoxic against the cancer cell lines HeLa (human cervical adenocarcinoma cell line) and MRC5-SV2 (human foetal lung cancer cell line), with $I C_{50}$ of 71.45 and $52.24 \mathrm{\mu g} / \mathrm{ml}$, respectively. The selectivity index (SI) for Compound 1 was 1.61 (IC $C_{50}$ against the normal human foetal lung fibroblast cell line MRC-5 was $84.33 \mu \mathrm{g} / \mathrm{ml})$, demonstrating better cancer cell-selectivity compared to doxorubicin with a SI of 1.28. The cytotoxic activity of Compound 1 in HeLa cells was also rapid, as shown by its concentrationand time-dependent $3 \mathrm{~h}$ and $6 \mathrm{~h}$ cytotoxicity profiles, an effect not observed with doxorubicin. Generation of reactive oxygen species at high concentrations of pentagalloylglucose to induce oxidative stress in cancer cells was identified as a mechanistic event that led to or resulted from its cytotoxicity.

(Continued on next page)
\end{abstract}

\footnotetext{
* Correspondence: bamit@oauife.edu.ng; A.A.Fatokun@ljmu.ac.uk

${ }^{1}$ Department of Pharmaceutical Chemistry, Faculty of Pharmacy, Obafemi

Awolowo University, lle-lfe, Osun State, Nigeria

${ }^{3}$ Centre for Natural Products Discovery (CNPD), School of Pharmacy and

Biomolecular Sciences, Liverpool John Moores University, Byrom Street,

Liverpool L3 3AF, UK

Full list of author information is available at the end of the article
}

C C The Author(s). 2020 Open Access This article is licensed under a Creative Commons Attribution 4.0 International License, which permits use, sharing, adaptation, distribution and reproduction in any medium or format, as long as you give appropriate credit to the original author(s) and the source, provide a link to the Creative Commons licence, and indicate if changes were made. The images or other third party material in this article are included in the article's Creative Commons licence, unless indicated otherwise in a credit line to the material. If material is not included in the article's Creative Commons licence and your intended use is not permitted by statutory regulation or exceeds the permitted use, you will need to obtain permission directly from the copyright holder. To view a copy of this licence, visit http://creativecommons.org/licenses/by/4.0/ The Creative Commons Public Domain Dedication waiver (http://creativecommons.org/publicdomain/zero/1.0/) applies to the data made available in this article, unless otherwise stated in a credit line to the data. 


\begin{abstract}
(Continued from previous page)
Conclusions: We suggest that pentagalloylglucose is selectively cytotoxic to cancer cells, and at high concentrations could exhibit pro-oxidant effects in those cells, as opposed to its general anti-oxidant effects in cells. Also, the presence of Compound 1 (pentagalloylglucose) in the plant and its cancer cell-selective cytotoxicity provide some rationale for the ethno-medicinal use of the plant's leaf extract for treating diseases associated with excessive cell proliferation. Further studies are required to dissect the molecular mechanisms and players differentially regulating the biphasic anti-oxidant and pro-oxidant effects of pentagalloylglucose in normal and cancer cells.
\end{abstract}

Keywords: Anacardium occidentale, Pentagalloyl glucose, Selectivity index, Cytotoxicity

\section{Background}

Anacardiaceae is a family of plants well known for its tannin-rich constituents. The taxa and the vegetative parts being investigated determine the type of constituent tannin(s). Most members of Anacardiaceae are trees or shrubs located mainly in tropical but also in subtropical and temperate regions of the world, while the family is subdivided into 5 tribes, based on morphological characteristics [1-3], namely: Anacardiaceae, Rhoeae, Spondiadeae, Semecarparpaceae, and Dobineeae. The plants in these tribes have been widely explored as sources of many biologically useful polyphenols. Therefore, the presence of polyphenols in a member tribe is of chemotaxonomic significance. Chemotaxonomy seeks to utilize chemical information to improve the classification of plants [4]. However, beyond this, the presence of certain chemical constituents in a particular plant species could have a significant influence on the array of biological activities that could be obtained from such plant and, therefore, the medicinal uses for which it could be harnessed.

Anacardium occidentale L., commonly referred to as Cashew, is a prominent member of the Anacardiaceae family. In Nigeria, it is one of the plants with multipurpose medicinal uses. Almost all parts of the cashew tree have medicinal uses. The leaf is especially a common component of the recipes for many ailments. Reported ethno-medicinal uses of the leaf formulation include treatment of inflammation, infection, sore throat, asthma and oxidative conditions [5, 6]. It is also used in the treatment of fevers [7-9], aches and pains $[8,10]$, inflammation of the extremities [11], and asthma [12]. Mustapha [13] indicated the use of the leaf extract of $A$. occidentale in the treatment of Human immunodeficiency virus/ Acquired immunodeficiency syndrome (HIV/AIDS) opportunistic infections in the Northern part of Nigeria. A. occidentale was shown to possess anti-inflammatory effects in some models of inflammation [14]. A leaf extract of the plant showed anti-inflammatory and analgesic effects in the carrageenan-induced rat paw oedema and acetic acidinduced writhing assays, respectively [15]. Towards explaining the rationale for the application of the leaf of this plant for the treatment of cancerous diseases in ethno-medicine, this study isolated, from the plant part for the first time, pentagalloylglucose, a polyphenol with multiple medicinal applications. The cancer cell-selective cytotoxicity of pentagalloylglucose was demonstrated at its high concentrations to be partly as a result of, or causal to, the induction of oxidative stress.

\section{Methods \\ Plant collection and preparation}

Leaves of $A$. occidentale were collected at Road 9 Junction of the Senior Staff Quarters, Obafemi Awolowo University, Nigeria, in July 2015. The vegetative part was identified by Mr. Ogunlowo A.A. of the Department of Pharmacognosy, Faculty of Pharmacy, Obafemi Awolowo University, Ile Ife, Nigeria, and a voucher specimen (Voucher no. FPI 2107) was deposited in the IFE Herbarium. The leaves were air-dried and milled to give $2.5 \mathrm{~kg}$ of powdered material. The powdered leaves were extracted with $96 \%$ ethanol. The extract was filtered and concentrated in-vacuo at $40^{\circ} \mathrm{C}$ to give $289 \mathrm{~g}(11.56 \% \mathrm{w} / \mathrm{w})$ of the crude ethanolic extract. The crude extract was dissolved in 200 $\mathrm{mL}$ of water and partitioned successively between water and $n$-hexane $(3 \times 500 \mathrm{~mL})$, water and ethyl acetate $(8 \mathrm{x}$ $250 \mathrm{~mL})$ and water and $n$-butanol $(4 \times 200 \mathrm{~mL})$ to give $n$ hexane (26.2 g), ethyl acetate (15.8 g), $n$-butanol (14.6 g) and aqueous $(210.4 \mathrm{~g})$ fractions. The ethyl acetate fraction (previously determined to be active against some cancer cell lines) (15.1 g) was dissolved in methanol and adsorbed on silica gel and allowed to dry. The dry powder was packed into a column of silica gel $(30 \times 3 \mathrm{~cm})$ and eluted in descending mode with varied proportions of solvent of increasing polarity from $100 \%$ hexane to $100 \%$ ethyl acetate to $50 \%$ methanol. The fraction that was eluted with $100 \%$ ethyl acetate was further subjected to repeated fractionation on silica gel and Sephadex LH-20 to give Compound $1(0.188 \mathrm{~g})$.

\section{Chromatography and spectroscopic analysis}

${ }^{1} \mathrm{H}$ and ${ }^{13} \mathrm{C}$ Nuclear magnetic resonance (NMR) spectra (for both 1D and 2D experiments) were obtained on the 
Bruker AV400 (IconNMR) Spectrometer at 400 and 100 $\mathrm{MHz}$, respectively, while the Liquid Chromatography Mass Spectroscopy (LCMS) analyses were carried out on an Agilent LCMS comprising a 1100 series LC/MSD Trap SL at the School of Chemistry and Physics of the University of KwaZulu-Natal in Pietermaritzburg, South Africa. Adsorption chromatography (open column) was carried out with Silica gel (ASTM 230-400 mesh, Merck). Size exclusion column chromatography was achieved on Sephadex LH-20 (Pharmacia) pre-swollen in a specified solvent before loading onto the column. The column eluate was analyzed by Thin Layer Chromatography (TLC) performed at room temperature using analytical silica gel $60 \mathrm{GF}_{254}$ pre-coated aluminum backed plates (Merck, $0.25 \mathrm{~mm}$ thick). The resulting spots on TLC plates were visualized under Ultraviolet (UV) light $(254 \mathrm{~nm})$ and detected by the use of $1 \%$ vanillin $/ \mathrm{H}_{2} \mathrm{SO}_{4}$.

\section{Cell culture}

The HeLa cell (immortalized human cervical cell line) and the MRC-5 SV2 cell (human foetal lung fibroblast line transfected with the virus SV40) were used as models of cancers, while the MRC- 5 cell (human foetal lung cell line) was used as a model of normal (non-cancerous) cells. [16]. They were cultured in Dulbecco's Modified Eagle Medium (DMEM) (4.5 g/L D-glucose) supplemented with $10 \%$ Foetal Calf Serum (FCS), 1\% LGlutamine $(2 \mathrm{mM})$ and $1 \%$ antibiotic-antimycotic solution (penicillin/streptomycin/amphotericin B) and maintained at $37^{\circ} \mathrm{C}$ in a humidified atmosphere of $5 \%$ $\mathrm{CO}_{2}$ and $95 \%$ air [16]. All cells were from the European Collection of Authenticated Cell Cultures (ECACC), Salisbury, UK

\section{Cell viability assay to determine toxicity of compound}

Compound $\mathbf{1}$ at concentrations ranging from 6.25 to $100 \mu \mathrm{g} / \mathrm{ml}$ was evaluated for the potential to alter the viability of HeLa, MRC-5 SV2 and MRC-5 cells. Cells were seeded into opaque, flat bottom, microclear 96-well plates at $7.5 \times 10^{5}$ cells $/ \mathrm{ml}\left(7.5 \times 10^{4}\right.$ cells per well at 100 $\mu \mathrm{l} /$ well) and incubated for $24 \mathrm{~h}$ at $37^{\circ} \mathrm{C}$ and $5 \% \mathrm{CO}_{2}$ to allow the cells to attach. After $24 \mathrm{~h}$, the medium was discarded and the wells treated with $100 \mu \mathrm{l}$ of the different concentrations of extracts prepared in growth medium. A set of untreated (negative) control wells was included in each plate as well as cells treated with doxorubicin (positive control) at concentrations between 0.1 and 20 $\mu \mathrm{M}$.

Following incubation for up to 48 hours, $10 \mu \mathrm{l}$ of the viability reagent MTT (3-(4,5-dimethylthiazol-2-yl)-2,5diphenyltetrazolium bromide; $5 \mathrm{mg} / \mathrm{ml}$ in PhosphateBuffered Saline (PBS)) was added to each well. After 2 hours of incubation with $\mathrm{MTT}$ at $37^{\circ} \mathrm{C}$, the medium was discarded and $100 \mu \mathrm{l}$ of DMSO was added to each well to dissolve the insoluble formazan formed. The absorbance at $570 \mathrm{~nm}$ was then determined with a microplate reader (CLARIO Star Microplate reader, BMG Labtech, UK) [16]. Each experiment was run in triplicate and repeated three independent times.

\section{Bright-field imaging to assess morphological damage}

In order to assess treatment-induced changes to the morphology of the cells, bright-field images were acquired on an Olympus CKX41 microscope fitted with an Olympus DP71 U-TVIX-2 camera, using the Olympus cellSens entry software [16].

\section{Reactive Oxygen Species (ROS) Assay (DCFDA Assay)}

HeLa cells were seeded into dark, clear-bottom 96-well microplates at $2.5 \times 10^{6}$ cells $/ \mathrm{ml}\left(2.5 \times 10^{5}\right.$ cells per well $)$. The cells were incubated at $37^{\circ} \mathrm{C}$ and allowed to adhere overnight. The medium was thereafter aspirated from each well, followed by rinsing with $1 \mathrm{X}$ buffer provided in the assay kit (Abcam, Cat. No. ab113851). The buffer was aspirated and the cells stained with $100 \mu$ l of diluted $2^{\prime}, 7^{\prime}$-dichlorofluorescein diacetate (DCFDA) solution $(25 \mu \mathrm{M})$. Stained cells were incubated for $45 \mathrm{~min}$ at $37^{\circ} \mathrm{C}$ in the dark. After $45 \mathrm{~min}$, DCFDA solution was removed, cells were rinsed with $1 \mathrm{x}$ buffer, the rinse buffer was removed and the cells were treated, in duplicate, with $100 \mu \mathrm{l}$ of Compound 1 (6.25 to $100 \mu \mathrm{g} / \mathrm{ml})$. The Fluorescence Intensity (FI) $(\mathrm{Ex} / \mathrm{Em}=485 / 535 \mathrm{~nm})$ of each well was then read (CLARIO Star Microplate reader, BMG Labtech, UK) at 3 and $18 \mathrm{~h}$ following treatment. Background wells (untreated or diluent-treated stained cells), as well as blank wells (medium only), were included in each experiment. Each experiment was repeated three times. Cellular ROS data were then analysed and presented as fold changes compared to the negative control.

\section{Data presentation and analyses}

For the viability assay data, the average viability of the negative control culture was taken as $100 \%$ and the average viability for every treatment was normalised to it. Values are indicated as Mean \pm SEM (standard error of the mean). Statistical analyses were conducted with the GraphPad Prism Software (Version 8.0.1) (GraphPad Software Inc., CA, USA). To assess statistically significant differences between means, analysis of variance (ANOVA) was used, followed by a post-hoc test for multiple comparisons (Tukey test), with a $\mathrm{p}<0.05$ considered statistically significant.

The $\mathrm{IC}_{50}$ value for each compound was calculated using GraphPad Prism (non-linear regression). Selectivity Index (SI) for Compound 1 or doxorubicin was calculated by dividing the $\mathrm{IC}_{50}$ for its cytotoxic effect in the 
normal cell (MRC5) by the $\mathrm{IC}_{50}$ for its cytotoxic effect in the cancer variant (MRC5-SV2).

\section{Results}

Spectroscopic data

Compound 1. IR $\left(\mathrm{cm}^{-\mathbf{1}}\right)$ 3324, 1698, 1608. ${ }^{\mathbf{1}} \mathbf{H}$ NMR (400 MHz, CD $\left.{ }_{3} \mathrm{OD}\right) .8 \mathrm{H}: 7.14\left(2 \mathrm{H}, \mathrm{s}, \mathrm{H}-2^{\prime \prime \prime} / 6^{\prime \prime \prime}\right), 7.09$ $\left(2 \mathrm{H}, \mathrm{s}, \mathrm{H}-2^{\prime} / 6^{\prime}\right), 7.01\left(2 \mathrm{H}, \mathrm{s}, \mathrm{H}-2^{\prime \prime} " / 6^{\prime \prime \prime}\right), 6.98(2 \mathrm{H}, \mathrm{s}, \mathrm{H}-$ 2" "'/6"'"), $6.94\left(2 \mathrm{H}, \mathrm{s}, \mathrm{H}-2^{\prime \prime} / 6^{\prime \prime}\right), 6.26(1 \mathrm{H}, \mathrm{d}, J=8.0 \mathrm{~Hz}$, $\mathrm{H}-1$ ), $5.90(1 \mathrm{H}, \mathrm{m}, \mathrm{H}-4), 5.65(1 \mathrm{H}, \mathrm{m}, \mathrm{H}-5), 5.61(1 \mathrm{H}, \mathrm{m}, \mathrm{H}-$ 2), $4.42(1 \mathrm{H}, \mathrm{m}, \mathrm{H}-3), 4.39(2 \mathrm{H}, \mathrm{m}, \mathrm{H}-6) .{ }^{13} \mathrm{C}$ NMR (100 $\left.\mathrm{MHz}, \mathrm{CD}_{3} \mathrm{OD}\right)$. $\delta \mathrm{c}: 93.8$ (CH, C-1), $74.1(\mathrm{CH}, \mathrm{C}-3), 72.2$ (CH, C-4), 70.8 (CH, C-2), $68.4(\mathrm{CH}, \mathrm{C}-5), 62.2\left(\mathrm{CH}_{2}, \mathrm{C}-6\right)$. Galloyl i: $119.7\left(\mathrm{CH}, \mathrm{C}-1^{\prime}\right), 110.3\left(\mathrm{CH}, \mathrm{C}-2^{\prime} / 6^{\prime}\right), 140.0(\mathrm{CH}$, C-4'), $146.2\left(\mathrm{CH}, \mathrm{C}-3^{\prime} / 5^{\prime}\right), 166.2\left(\mathrm{C}=\mathrm{O}, \mathrm{C}-7^{\prime}\right)$, Galloyl ii: $120.2\left(\mathrm{CH}, \mathrm{C}-1^{\prime \prime}\right), 110.3\left(\mathrm{CH}, \mathrm{C}-2 " / 6^{\prime \prime}\right), 140.1(\mathrm{CH}, \mathrm{C}-$ 4")146.4 (CH, C-3"/5"), 166.9 (C=O, C-7"); Galloyl iii; $121.1\left(\mathrm{CH}, \mathrm{C}-1^{\prime \prime \prime}\right), 110.7\left(\mathrm{CH}, \mathrm{C}-2{ }^{\prime \prime \prime} / 6^{\prime \prime}\right), 146.5(\mathrm{CH}, \mathrm{C}-$ 3"'/5"'), $140.8\left(\mathrm{CH}, \mathrm{C}-44^{\prime \prime \prime}\right), 167.9(\mathrm{C}=\mathrm{O}, \mathrm{C}-7 " ')$; Galloyl iv; $120.2(\mathrm{CH}, \mathrm{C}-1 " \prime \prime), 110.4\left(\mathrm{CH}, \mathrm{C}-2{ }^{\prime \prime \prime} / 6^{\prime \prime \prime}\right), 146.4$ (CH, C-3"' '/5"' '), 140.3 (CH, C-4"' '), 167.0 (C=O, C-7"' '). Galloyl v: $120.2(\mathrm{CH}, \mathrm{C}-1$ "' ' '), 110.4 (CH, C-2"'"'/6"', '), $146.4(\mathrm{CH}, \mathrm{C}-3$ "'"'/5"'"'), 140.3 (CH, C-4"'"'), 167.0 $\left(\mathrm{C}=\mathrm{O}, \mathrm{C}-7^{\prime \prime \prime \prime \prime)}\right.$. TOF HRMS $\boldsymbol{m} / \boldsymbol{z} 963.1135[\mathrm{M}+\mathrm{Na}]^{+}$(calculated 963.1080).

\section{Structural elucidation of the isolated compound}

Compound 1 was isolated as a brown amorphous powder. The compound gave a strong blue-black colour on the thin layer chromatography when sprayed with ferric chloride, indicating the presence of phenolic moiety. IR spectrum displayed absorption at 3324, 1698, 1608, 1536 $\mathrm{cm}^{-1}$. Positive Time-of-Flight High Resolution Mass Spectrometry (TOF HRMS) gave a signal at $\mathrm{m} / \mathrm{z}$ $963.1135[\mathrm{M}+\mathrm{Na}]^{+}$(calculated 963.1080) for a molecular mass $\mathrm{C}_{41} \mathrm{H}_{32} \mathrm{O}_{26}$. The proton NMR spectrum displayed

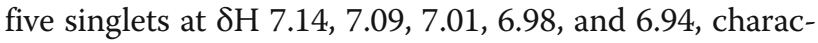
teristic of multiply substituted gallotannins. The appearance of a doublet at $6.26 \mathrm{ppm}$ with a large coupling constant $(J=8.4 \mathrm{~Hz})$ indicates the presence of a $\beta$ anomeric proton. The sugar protons were assigned based on the COSY and HMBC spectra. In the COSY spectrum, these pairs of correlating protons were observed between the signals at $\delta \mathrm{H} 6.26 / 5.61 ; 5.61 / 6.26$, 4.42, $5.90 / 5.65$, while in the HMBC spectrum long range correlations were observed between the protons at $\delta H \quad 6.26$ and $\delta c 72.9,164.7 ; \delta H 4.42$ and $\delta c$ 69.5, 166; $\delta H 5.90$ and $\delta c$ 62.1, 73.0, 92.6 and 166. Each galloyl group was placed based on the correlation between the sugar protons as well as the aryl singlet protons with the galloyl carbonyl carbons. Compound $\mathbf{1}$ was identified as $\beta$-penta-O-galloyl glucose (PGG) (molecular weight: 940.68) (Figure 1) by comparison of the spectroscopic data with literature values [17].

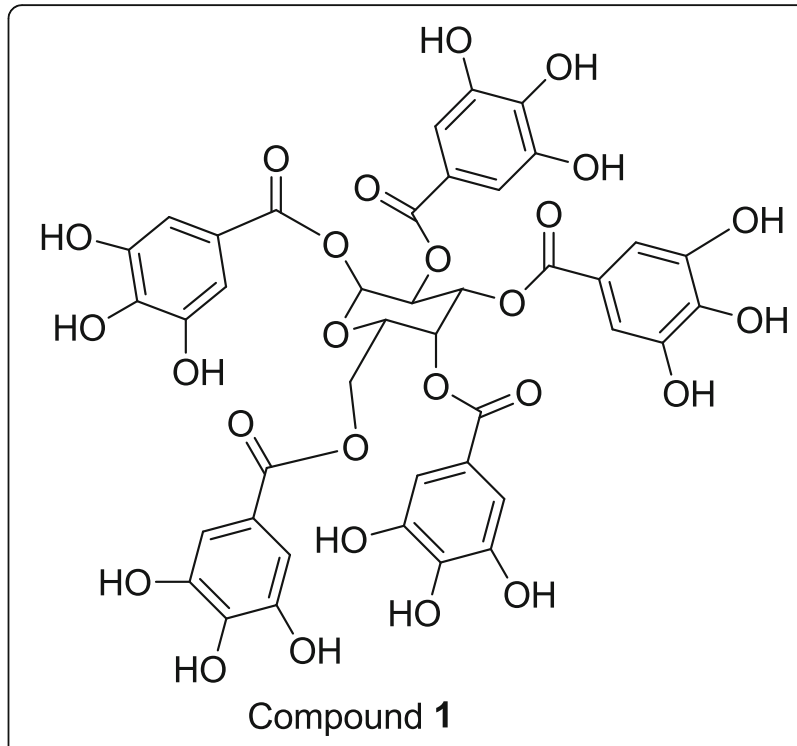

Fig. 1 Structure of isolated Compound 1

\section{Cytotoxicity of the isolated compound}

Compound 1 showed concentration-dependent toxicity to HeLa, MRC5 and MRC5-SV2 cells following 24 h exposure to varying concentrations up to $100 \mu \mathrm{g} / \mathrm{ml}$ (Figure 2). The $\mathrm{IC}_{50}$ obtained for Compound 1 was $71.45 \mu \mathrm{g} / \mathrm{ml}(76 \mu \mathrm{M})$, $52.24 \mu \mathrm{g} / \mathrm{ml}(56 \mu \mathrm{M})$ and $84.33 \mu \mathrm{g} / \mathrm{ml}(90 \mu \mathrm{M})$ in HeLa, MRC5-SV2 and MRC5 cells respectively; the selectivity index for Compound 1, which is the ratio of its $\mathrm{IC}_{50}$ in MRC5 and MRC5-SV2 cells, was calculated as 1.61. Doxorubicin, used as a standard anti-cancer drug, also demonstrated concentration-dependent toxicity to HeLa, MRC5 and MRC5-SV2 cells following $24 \mathrm{~h}$ exposure to it (Figure 2 ), with $\mathrm{IC}_{50}$ of $4.65,31.70$ and $40.64 \mu \mathrm{M}$ in HeLa, MRC5SV2 and MRC5 cells respectively. The selectivity index for doxorubicin was 1.28 .

The concentration-dependent toxicity of Compound 1 and that of the positive control doxorubicin were correlated with morphological damage that worsened as the concentration of each compound increased. As shown in Figure 3 for the HeLa, MRC5-SV2 and MRC5 cells, a higher concentration of Compound 1 or doxorubicin caused loss of cells and rounding up of several or nearly all remaining cells, while control cells not exposed to either compound were confluent and their connections were intact.

While the MRC5-SV2 cell was more sensitive to Compound 1 than the HeLa cell, it was nearly seven times less sensitive to doxorubicin than the HeLa cell. Compound 1 also showed better selectivity for cancer cells (as against normal cells) than doxorubicin. We thus decided to explore in a cancer cell aspects of the time course of its induction of cytotoxicity by comparing its effects with those of doxorubicin, following treatment 

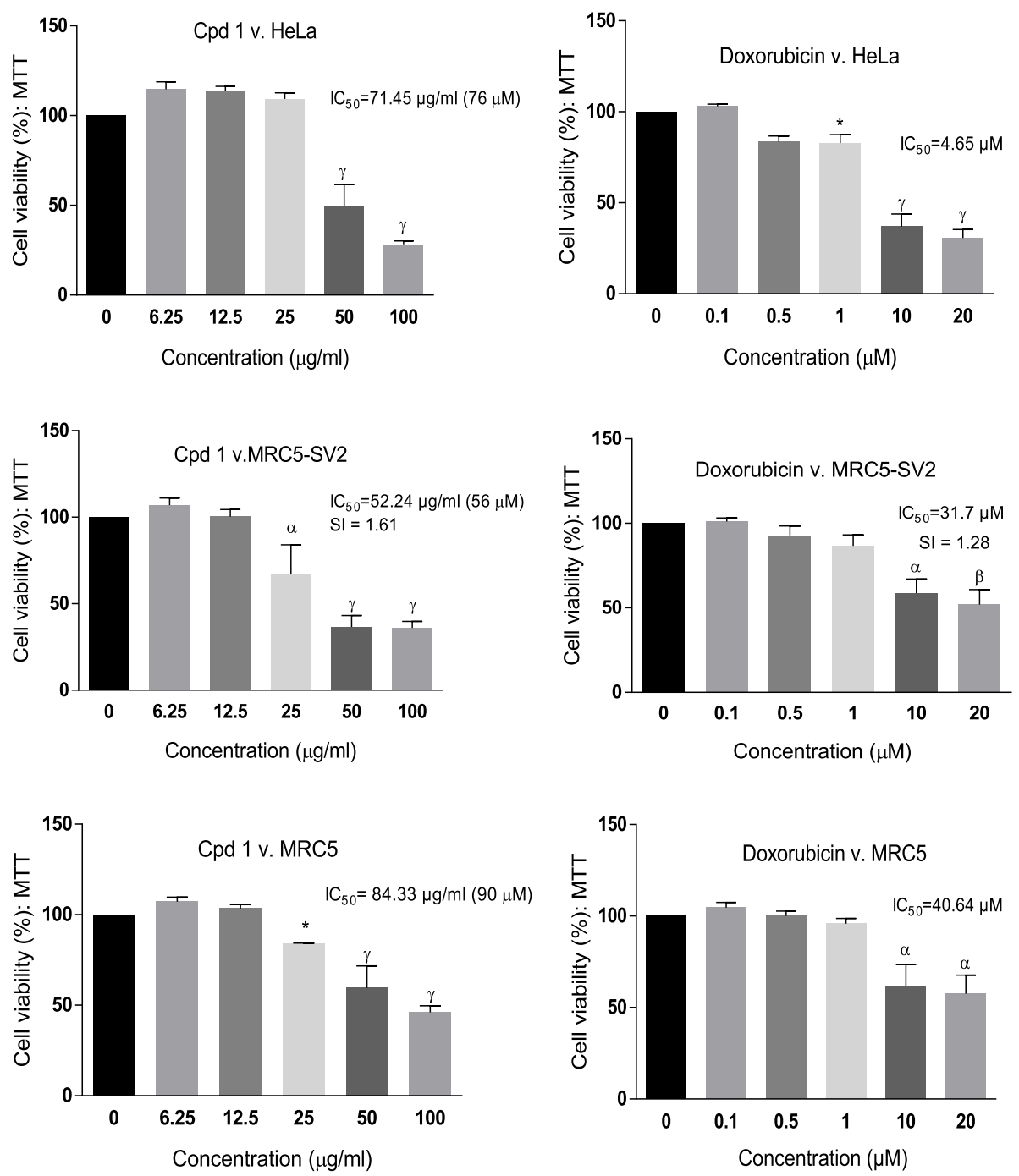

Fig. 2 Cell viability (\%) of HeLa, MRC5-SV2 and MRC5 cells following $24 \mathrm{~h}$ exposure to Compound 1 (Cpd 1) and doxorubicin. Each bar represents mean \pm SEM $(n=3) ;{ }^{*} p<0.05,{ }^{a} p<0.01,{ }^{\beta} p<0.001,{ }^{\gamma} p<0.0001$ vs. negative control using one-way ANOVA followed by Dunnett's post hoc multiple-comparison test. $\mathrm{SI}$ is Selectivity Index.

with each compound at the same range of concentrations as was tested before but for much shorter durations of $3 \mathrm{~h}$ and $6 \mathrm{~h}$. This was assessed using the HeLa cell that was less sensitive to Compound 1 than doxorubicin.

As shown in Figure 4, following $3 \mathrm{~h}$ and $6 \mathrm{~h}$ exposure of HeLa to Compound 1 and doxorubicin, Compound 1 demonstrated concentration- and time-dependent toxicity, which was significant at 50 and $100 \mu \mathrm{g} / \mathrm{ml}$, while doxorubicin showed no toxicity at the two time points. This observation establishes a key difference in the cytotoxicity time-course profiles of Compound $\mathbf{1}$ and doxorubicin. While Compound 1 rapidly induced cytotoxicity, initiated from as early as $3 \mathrm{~h}$ following exposure of cells to it and progressively increasing up to $24 \mathrm{~h}$, doxorubicin's toxicity revealed a much-slower time-course, with significant, concentration-dependent toxicity only observed after $24 \mathrm{~h}$ exposure to it. For drug discovery and development purposes, this property of Compound $\mathbf{1}$ could make it uniquely promising, as a shorter time of exposure to an anti-cancer agent could ensure less damage to normal cells and less side effects.

Induction of reactive oxygen species (ROS) as a potential mechanism by which compound elicits cytotoxicity As we established Compound $\mathbf{1}$ as rapidly and selectively cytotoxic to cancer cells, we assessed whether the generation of ROS was a mechanism by which it induced its toxicity in cancer cells, at least, in part. Figure 5 reveals that, at $3 \mathrm{~h}$ post-treatment in HeLa cells, Compound 1 up to $25 \mu \mathrm{g} / \mathrm{ml}$ did not induce significant ROS but at $100 \mu \mathrm{g} / \mathrm{ml}$ caused a significant 


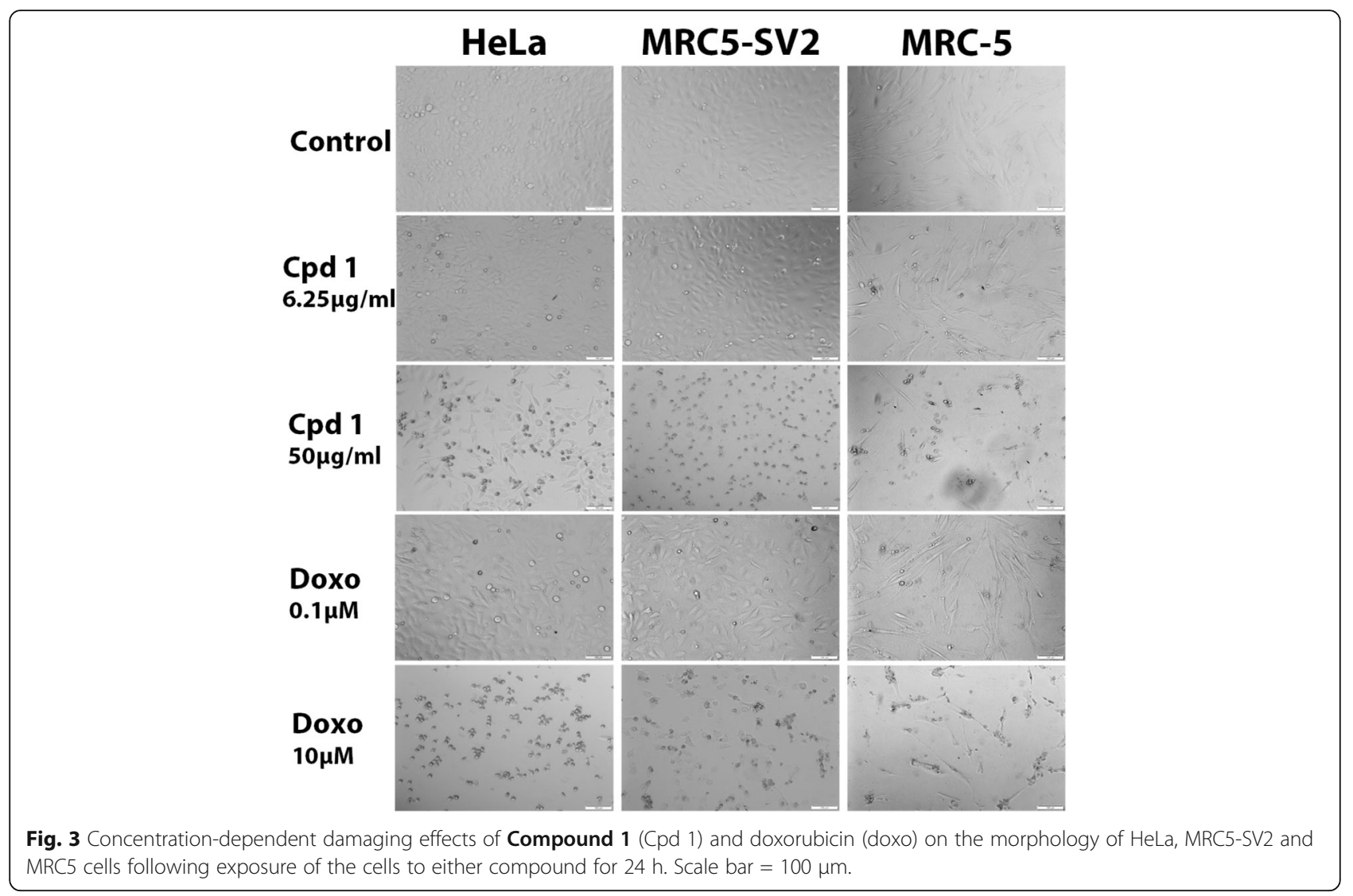

increase in ROS levels. This almost 3-fold increase in ROS could be correlated with an almost $50 \%$ decrease in viability at the $3 \mathrm{~h}$ time point (cf. Figure 4, top panel, left hand side - for $3 \mathrm{~h}$ ).

\section{Discussion}

We have previously reported the cytotoxicity of the crude extract of the leaf of Anacardium occidentale [18]. The results from the current study demonstrate the cancer cell-selective cytotoxicity of pentagalloylglucose obtained from the leaf extract. At high concentrations, the observed cytotoxicity of pentagalloylglucose is partly as a result of, or causal to, the induction of oxidative stress. Reactive oxygen species (ROS) have been implicated in DNA mutations, aging, and cell death [19]. While low-to-moderate ROS levels can be beneficial to normal cells by promoting proliferation pathways, high ROS levels can be detrimental to normal and tumour cells and induce cell death [20]. Some antineoplastic drugs that are currently used for cancer chemotherapy (e.g., doxorubicin, taxanes, vinca alkaloids, and antimetabolites) induce high levels of oxidative stress [21, 22], by which they kill cancer cells.

It should be noted that pentagalloylglucose has been generally reported to be an antioxidant, with some reports establishing it as a potent antioxidant [23-26] and potentially useful in chemoprevention [27], thus suggesting it should be relatively non-cytotoxic, which might appear to contrast with observations of its cytotoxicity and, at high concentrations, its pro-oxidant effect (induction of oxidative stress) in cancer cells reported in this paper. However, consistent with our findings, previous studies undertaken using cell cultures, as we did, have shown that pentagalloylglucose could be involved in eliciting anti-cancer effects through mechanisms including pro-apoptosis, anti-proliferation, anti-angiogenesis, anti-metastasis and inhibition of glycoprotein [28]. Besides, Kantapan et al. [29] recently reported that extracts containing pentagalloylglucose could promote intracellular ROS production and induce apoptosis in cancer cells, although it was not demonstrated whether those effects could be solely or partly attributed to the presence of pentagalloylglucose, as two other constituents were found to be present in the extract. Lin et al. [30], who used cultured cells (HepG2, 293T, HEp-2, MRC-5) grown and treated in conditions very similar to ours (DMEM supplemented with $10 \%$ fetal calf serum, 24 h treatment, MTT assay), showed pentagalloylglucose lacked toxicity to the cells up to $50 \mu \mathrm{M}$ but did not investigate higher concentrations.

It is generally recognised that some antioxidant molecules are capable of exhibiting an antioxidant-pro-oxidant switch, depending on a number of factors, including the 

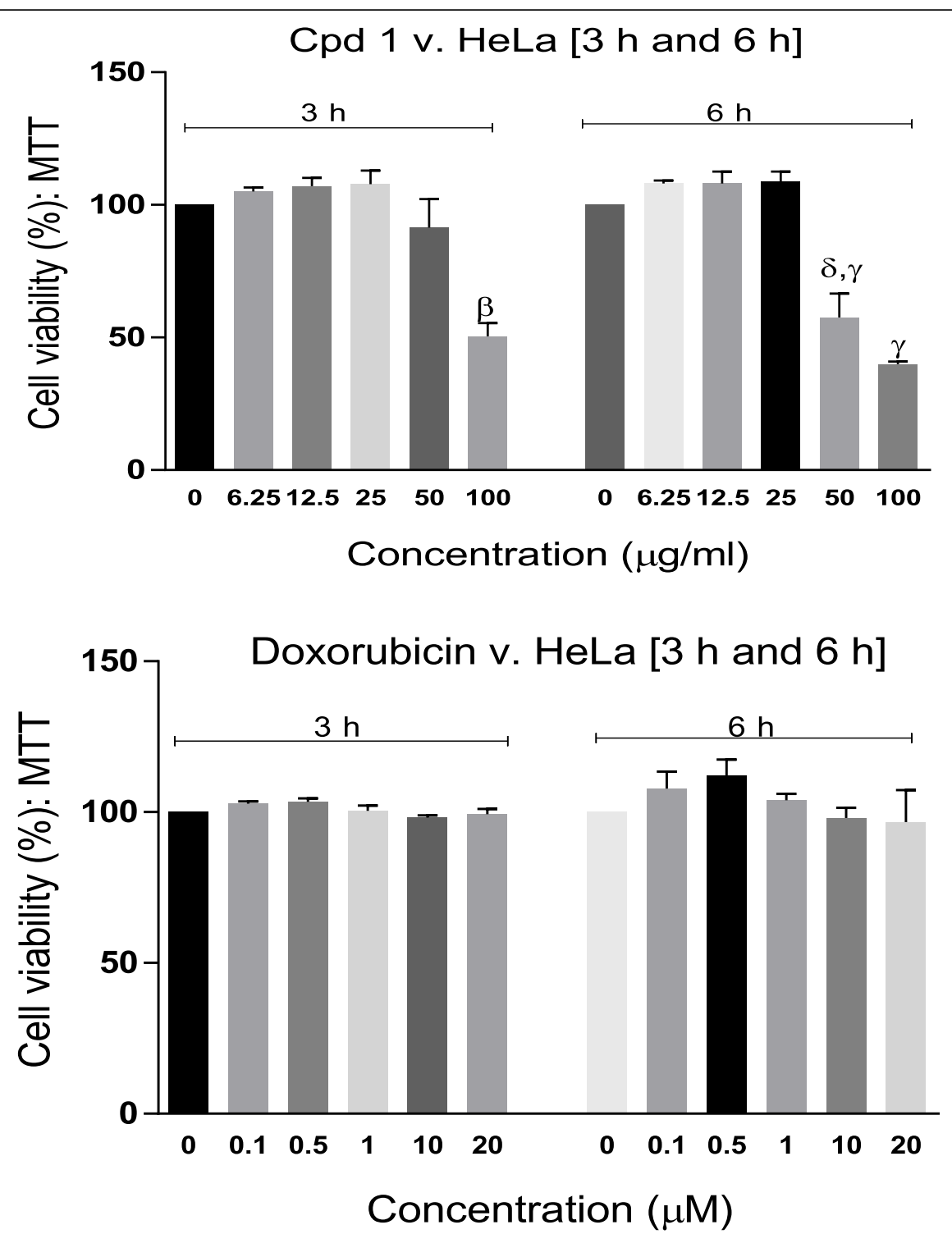

Fig. 4 Cell viability (\%) of HeLa cells following $3 \mathrm{~h}$ and $6 \mathrm{~h}$ exposures to Compound 1 (Cpd 1) and doxorubicin. Each bar represents mean \pm $\operatorname{SEM}(n=3) ;{ }^{\beta} p<0.001,{ }^{\gamma} p<0.0001$ vs control, ${ }^{\delta} p<0.01$ vs corresponding $3 \mathrm{~h}$ observation using one-way ANOVA followed by Dunnett's post hoc multiple-comparison test.

redox state of the cellular environment or the nature of the pathology in question. We reckon that, while pentagalloylglucose is generally antioxidant in nature, it could, under certain conditions, especially in cancer cells and at high concentrations, generate ROS, consistent with a prooxidant effect, and induce cytotoxicity. While our work showed that pentagalloylglucose concentrations above 25 $\mu \mathrm{M}$ but below $100 \mu \mathrm{M}$ could induce rapid cytotoxicity in cancer cells, there was no evidence that the cytotoxicity involved significant ROS, and it is thus reasonable to consider it to be independent of ROS, meaning other toxic mechanisms were involved. However, at high concentrations (100 $\mu \mathrm{M}$ and above), the toxicity is suggested to result from, or cause, substantial ROS. Overall, we suggest a dynamic and complex scenario in which cell toxicity, where it occurs, is independent of, results from, causes, or is synergistic with, elevated ROS levels.

Taken together, the data show that Compound 1, identified as $\beta$-penta-O-galloyl glucose, could induce rapid and selective cytotoxicity in cancer cells, which at high concentrations could be linked to oxidative stress. Further studies will identify the molecular mechanisms and players responsible for the anti-oxidant and pro-oxidant effects of pentagalloylglucose in normal and cancer cells.

\section{Conclusions}

This study isolated pentagalloyl glucose, a functionally valuable gallotannin from the leaf extract of Anacardium 


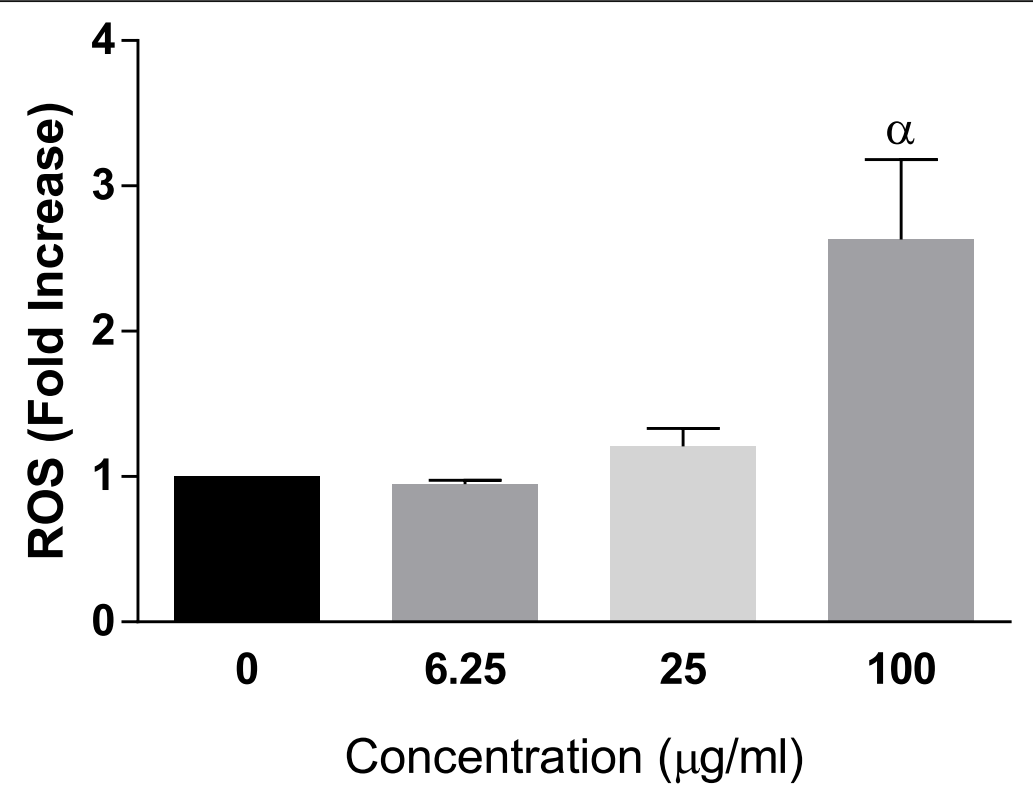

Fig. 5 Concentration-dependent increases in intracellular Reactive Oxygen Species (ROS) elicited by Compound 1 in HeLa cells, presented as fold increases compared to the negative control, following $3 \mathrm{~h}$ exposure of HeLa cells to Compound 1. Each bar represents Mean $\pm S E M(n=3) ;{ }^{a} p<$ 0.01 versus control using one-way ANOVA followed by Dunnett's post hoc multiple-comparisons test.

occidentale for the first time. Our results show that pentagalloylglucose is more toxic to cancer cells than to normal cells, produces rapid decreases in tumour cell populations, and at higher concentrations generates ROS, leading to oxidative stress in cancer cells. The presence of the compound pentagalloylglucose in the plant species is of chemotaxonomic significance and partly validates the use of the leaf extract of Anacardium occidentale in ethno-medicine for treating cancers and related pathologies.

\section{Abbreviations}

DCFDA: 2',7'-dichlorofluorescin diacetate; DMEM: Dulbecco's Modified Eagle Medium; DMSO: Dimethyl sulfoxide; DNA: Deoxyribonucleic acid; FCS: Foetal Calf Serum; HIV/AIDS: Human immunodeficiency virus/ Acquired immunodeficiency syndrome; HRMS: High-resolution mass spectrometry; IR: Infrared Spectroscopy; LCMS: Liquid Chromatography Mass Spectrometry; MTT: 3-(4,5-dimethylthiazol-2-yl)-2,5-diphenyltetrazolium bromide; NMR: Nuclear magnetic resonance; ROS: Reactive Oxygen Species; SEM: Standard Error of Mean; SI: Selectivity Index; TLC: Thin Layer Chromatography; TOF: Time-of-Flight; UV: Ultraviolet

\section{Acknowledgements}

None

\section{Authors' contributions}

BJT and AAF designed the study; BJT, AAF and TDP carried out experiments, analysed data and wrote the manuscript; $F R v H$ and AAF supervised the research and provided research resources; AAF reviewed the final draft of the manuscript. All authors read and approved the final manuscript.

\section{Funding}

None

\section{Availability of data and materials}

Data sets have not been deposited in any repository but are available from corresponding authors upon request
Ethics approval and consent to participate

Not applicable

\section{Consent for publication}

Not applicable

\section{Competing interests}

The authors declare no competing interests.

\section{Author details}

'Department of Pharmaceutical Chemistry, Faculty of Pharmacy, Obafemi Awolowo University, lle-lfe, Osun State, Nigeria. ${ }^{2}$ School of Chemistry and Physics, Pietermaritzburg Campus, University of KwaZulu-Natal, Private Bag X01, Scottsville 3209, South Africa. ${ }^{3}$ Centre for Natural Products Discovery (CNPD), School of Pharmacy and Biomolecular Sciences, Liverpool John Moores University, Byrom Street, Liverpool L3 3AF, UK.

Received: 12 May 2020 Accepted: 8 September 2020

Published online: 21 September 2020

\section{References}

1. Wannan BS. Analysis of Generic Relationships in Anacardiaceae. Blumea Biodiversity, Evol Biogeography Plants. 2006;51 (1):165-95.

2. Pell S, Mitchell J, Miller A, Lobova T. Anacardiaceae, Vol. 10. Berlin Heidelberg: Flowering Plants, Eudicots: Sapindales, Cucurbitales, Myrtaceae Springer-Verlag; 2011. p. 7-50.

3. Singh S, Vrishni S, Singh BK, Rahman I, Kakkar P. Nrf2-ARE stress response mechanism: a control point in oxidative stress-mediated dysfunctions and chronic inflammatory diseases. Free Radic Res. 2010;44(11):1267-88.

4. Schulze-Kaysers N, Feuereisen MM, Schieber A. Phenolic compounds in edible species of the Anacardiaceae family - a review. RSC Advances. 2015; 5(89):73301-14.

5. Iwu M. Handbook of African Medicinal plants. Boca Raton, FL: CRC press; 1993. p. 183-4.

6. Oliver-Bever B. Medicinal Plants in Tropical West Africa: Cambridge University Press; 1986.

7. Barrett B. Medicinal Plants of Nicaragua's Atlantic Coast. Econ Botany. 1994; 48(1):8-20.

8. Coe FG, Anderson GJ. Ethnobotany of the garifuna of Eastern Nicaragua. Econ Botany. 1996;50(1):71-107. 
9. Gill LS, Akinwumi C. Nigerian folk medicine: Practices and beliefs of the ondo people. J Ethnopharmacol. 1986;18(3):257-66.

10. Coe FG, Anderson GJ. Screening of medicinal plants used by the Garifuna of Eastern Nicaraqua for bioactive compounds. J Ethnopharmacol. 1996;53(1): 29-50.

11. Gupta MP, Arias TD, Correa M, Lamba SS. Ethnopharmacognostic Observations on Panamanian Medicinal Plants. Part I. Quarterly J Crude Drug Res. 1979;17(3-4):115-30.

12. Girón LM, Freire V, Alonzo A, Cáceres A. Ethnobotanical survey of the medicinal flora used by the Caribs of Guatemala. J Ethnopharmacol. 1991; 34(2-3):173-87.

13. Mustafa AA, OO F, AA A, DA A. Ethnobotanical Survey of Medicinal Plants Used in the Treatment of Diabetes in Irepodun Local Government Area of Osun State, Nigeria. Greener J Biological Sci. 2014;4(2):059-68.

14. Mota ML, Thomas G, Barbosa Filho JM. Anti-inflammatory actions of tannins isolated from the bark of Anacardium occidentale L. J Ethnopharmacol. 1985;13(3):289-300.

15. Sokeng S, Kamtchouing P, Watcho P, Jatsa H, Moundipa P. Hypoglycemic activity of Anacardium occidentale $L$. aqueous extract in normal and streptozotocin-induced diabetic rats. Diabetes Res. 2001;36(1):1-9.

16. Ajibade PA, Fatokun AA, Andrew FP. Synthesis, characterization and anticancer studies of $\mathrm{Mn}(\mathrm{II}), \mathrm{Cu}(\mathrm{II}) \mathrm{Zn}(\mathrm{II})$ and Pt(II) dithiocarbamate complexescrystal structures of the $\mathrm{Cu}(\mathrm{II})$ and Pt(II) complexes. Inorg Chimica Acta. 2020;504:119431.

17. Fouad MA, Abdel-Hafeez AS. Chemical and biological Studies of the methanolic extarct of Primula elatior L. seeds. Bull Pharmaceutical Sci. 2009;32:111-23.

18. Taiwo BJ, Fatokun AA, Olubiyi OO, Bamigboye-Taiwo OT, van Heerden FR, Wright CW. Identification of compounds with cytotoxic activity from the leaf of the Nigerian medicinal plant, Anacardium occidentale L. (Anacardiaceae). Bioorg Med Chem. 2017;25(8):2327-35.

19. Orrenius S, Gogvadze V, Zhivotovsky B. Mitochondrial Oxidative Stress: Implications for Cell Death. Annu Rev Pharmacol Toxicol. 2007;47(1):143-83.

20. Gorrini C, Harris IS, Mak TW. Modulation of oxidative stress as an anticancer strategy. Nat Rev Drug Discovery. 2013;12(12):931-47.

21. Conklin KA. Chemotherapy-associated oxidative stress: impact on chemotherapeutic effectiveness. Integr Cancer Ther. 2004;3(4):294-300.

22. Barrera G. Oxidative stress and lipid peroxidation products in cancer progression and therapy. ISRN Oncol. 2012;2012:137289.

23. Wang K-J, Yang C-R, Zhang Y-J. Phenolic antioxidants from Chinese toon (fresh young leaves and shoots of Toona sinensis). Food Chem. 2007;101(1):365-71.

24. Abdelwahed A, Bouhlel I, Skandrani I, Valenti K, Kadri M, Guiraud P, Steiman R, Mariotte A-M, Ghedira K, Laporte F, et al. Study of antimutagenic and antioxidant activities of Gallic acid and 1,2,3,4,6-pentagalloylglucose from Pistacia lentiscus: Confirmation by microarray expression profiling. Chem Biol Interact. 2007;165(1):1-13.

25. Kim B-H, Choi MS, Lee HG, Lee S-H, Noh KH, Kwon S, Jeong AJ, Lee H, Yi EH, Park JY. Photoprotective potential of penta-O-galloyl- $\beta$-Dglucose by targeting NF-KB and MAPK signaling in UVB radiation-induced human dermal fibroblasts and mouse skin. Mol Cells. 2015;38(11):982.

26. Torres-León C, Ventura-Sobrevilla J, Serna-Cock L, Ascacio-Valdés JA, ContrerasEsquivel J, Aguilar CN. Pentagalloylglucose (PGG): A valuable phenolic compound with functional properties. J Funct Foods. 2017;37:176-89.

27. Zhang J, Li L, Kim S-H, Hagerman AE, Lü J. Anti-Cancer, Anti-Diabetic and Other Pharmacologic and Biological Activities of Penta-Galloyl-Glucose. Pharm Res. 2009;26(9):2066-80.

28. Li L, Shaik AA, Zhang J, Nhkata K, Wang L, Zhang Y, Xing C, Kim S-H, Lü J. Preparation of penta-O-galloyl- $\beta$-d-glucose from tannic acid and plasma pharmacokinetic analyses by liquid-liquid extraction and reverse-phase HPLC. J Pharm Biomed Anal. 2011:54(3):545-50.

29. Kantapan J, Paksee S, Chawapun P, Sangthong P, Dechsupa N. Pentagalloyl Glucose- and Ethyl Gallate-Rich Extract from Maprang Seeds Induce Apoptosis in MCF-7 Breast Cancer Cells through Mitochondria-Mediated Pathway. Evid Based Complement Alternat Med. 2020;2020:1-19.

30. Lin M-H, Chang F-R, Hua M-Y, Wu Y-C, Liu S-T. Inhibitory Effects of 1,2,3,4,6Penta-O-Galloyl- $\beta$-d-Glucopyranose on Biofilm Formation byStaphylococcus aureus. Antimicrob Agents Chemother. 2010;55(3):1021-7.

\section{Publisher's Note}

Springer Nature remains neutral with regard to jurisdictional claims in published maps and institutional affiliations.

\section{Ready to submit your research? Choose BMC and benefit from:}

- fast, convenient online submission

- thorough peer review by experienced researchers in your field

- rapid publication on acceptance

- support for research data, including large and complex data types

- gold Open Access which fosters wider collaboration and increased citations

- maximum visibility for your research: over $100 \mathrm{M}$ website views per year

At BMC, research is always in progress.

Learn more biomedcentral.com/submissions 